\title{
PRODUCTIVITY EFFECTS OF WORKER PARTICIPATION IN MANAGEMENT, PROFIT-SHARING, WORKER OWNERSHIP OF ASSETS AND UNIONIZATION IN U.S. FIRMS
}

\author{
Michael A. CONTE* \\ University of New Orleans, New Orleans, LA 70148, USA \\ Jan SVEJNAR* \\ University of Pittsburgh, Pittsburgh, PA 15260, USA
}

Final version received November 1987

\begin{abstract}
In this paper we provide our first econometric estimates of the effect of worker participation in decision-making, ownership and profits on productive efficiency. Participation has the potential for exerting several conflicting influences on firm performance simultaneously. As a result both the direction and magnitude of its impact are empirical issues. Previous studies have empirically measured the impact of each of these forms of participation; however, no prior study has controlled for the influence of the other forms. Because of the potential for correlation among these forms of participation, it is possible that omitted variables bias has affected the previous results. Using a new panel data sel with simultaneous measures of all four types of participation in U.S. manufacturing establishments, we model participation as disembodied technical change, and estimate production function coefficients for each type while controlling for the others. We use both OLS and instrumental variables in order to guard against potential simultaneity. The IV results indicate that participation in decision-making has a large positive productivity effect while the impacts of unionization and profit-sharing depend upon regression specification. Moderate amounts of indirect worker ownership affect productivity positively, while the estimated effect of direct worker ownership is negative. However, this last result may reflect the industrial concentration of the direct ownership firms in our sample.
\end{abstract}

\section{Introduction}

In both capitalist and socialist countries, there has been substantial growth of and increasing interest in participative organizations over the past 20 years. In spite of these developments, there is still relatively little published information on how participatory firms are organized and how they perform. Only recently have there been published results about the effects of increased participation on firm performance, ${ }^{1}$ and there remains little solid information

*The authors gratefully acknowledge the financial support of the U.S. Department of Labor (Grant no. 21-36-80-21) and the National Science Foundation (Grant no. SES8420801), and wish to thank Robert E. Moore and Steven J. Arbour for valuable computational assistance.

${ }^{1}$ These include articles in Jones and Svejnar (1982), Defourney, Estrin and Jones (1985), Jones (1985), Jones and Svejnar (1985) and Estrin, Jones and Svejnar (1987). 
on whether the effects themselves vary according to the type of firm under consideration or the form of participation. Although many advocates stress welfare aspects of worker participation in justifying supportive intervention, the question of operational efficiency is clearly a crucial and as yet not a completely resolved one. In this paper we provide our first econometric estimates of the effect of various forms of worker participation on productive efficiency.

In section 2, we briefly discuss the main hypotheses about the productivity effects of worker participation in decision-making, ownership and profits and indicate some important considerations in estimating these effects and drawing general conclusions. In section 3 , we present our data set which is uniquely suited to analyzing the independent influences of employee participation in ownership, profits and decision-making within the firm, while controlling for degree of unionization. In this section, we also outline our econometric framework for estimating the magnitudes of these effects. In section 4 we discuss our econometric results and in section 5 we draw conclusions.

\section{Theoretical approach and hypotheses}

As was pointed out in earlier papers [e.g., Jones and Svejnar (1985)], there is at present no tight theory which would yield empirical predictions about the effects of different forms of worker participation on productive efficiency (total factor productivity). The most highly formalized approach to studying the performance impact of non-managerial participation in decision-making, ownership and profit within the firm is that of Jensen and Meckling $(1976,1979)$, who see participation of any type as always having deleterious effects on firm performance. Jensen and Meckling's analysis is based on the theory of contractual agency relationships. This approach analyzes the effects of primarily explicit contracts specifying the disposition of costs and rewards among principles and agents in the firm. The stipulations of these contracts in large part determine the behavior of agents in the firm. As a result, it is reasonable to formally specify the nature of these intra-firm agreements as an element in the firm's production function.

Much of the work to date has adopted such a production function framework. The particular contribution of Jensen and Meckling's work is to supply a rationale for negative values for the coefficients on the variables which measure participatory elements in the firm's production function.

According to Jensen and Meckling, the object of external shareholders in a corporation is wealth maximization, whereas the object of managers is their own utility maximization. Hence, shareholders must monitor the managers, which is costly. These monitoring costs increase with the number of agents, making a broad dispersion of decision-making rights highly inefficient. It is 
precisely this broad distribution of decision-making rights which defines the participative firm.

The residual loss will also be greater in participative firms. By definition, the greater the number of persons with contractual rights to sharing in residual gains, the smaller will be the incentive for each to undertake the effort and stress associated with reaping these gains. This element of the criticism applies more to profit-sharing and to worker ownership than to the sharing of decision-making rights.

The agency cost framework, based on a model of individual utility maximization, leads Jensen and Meckling to conclude that participative arrangements are inevitably inefficient. However, adopting a similar framework, but one based on collusive group behavior, leads other authors, including Thomas and Logan (1982), Vanek (1970), Horvat (1982), and Cable and Fitzroy (1980a,b), to conclude just the opposite. Cable and Fitzroy (1980b) predict 'a positive collusion to maximize joint wealth', implying that the residual loss will actually be smaller in participative firms than in traditional firms due to a greater identification by members of the firm with commonly held goals. In part, this argument rests upon extra-economic motivations, such as solidarity [emphasized in Vanek (1970)], but it also results from decreased monitoring costs [Bradley and Gelb (1981)].

Additionally, if there is an asymmetry of information in the firm due to the fact that employees have specific knowledge about the workplace and the behavior of fellow workers, then participatory schemes may give workers greater incentives to provide information to managers. This may result in an increase of managerial control over the workplace in spite of the apparent yielding of certain elements of traditional managerial discretion. Voluntary information sharing may also decrease the costs of monitoring workers. The phenomenon of increased total control in participative firms has been noted and subjected to measurcment in the social-psychological literature [Tannenbaum (1974)], while the lowering of monitoring costs in participative environments has proven to be measurably present in the Mondragon cooperatives in Spain [Bradley and Gelb (1981)].

These arguments indicate that the observed effect of increased participation in decision-making, ownership and profits on firm performance is a composite of conflicting effects and that its direction and magnitude are empirical issues.

Several features of the participatory firms make estimation empirically complex. One issue is self-selection, both at the level of the firm and of the employee. Most producer cooperatives were started as cooperatives, both in Europe and in the U.S. It is thercforc safc to regard their ownership status as exogenous (predetermined) for purposes of estimating the effects of ownership status. However, only a small percentage of ESOP (employee stock ownership plan) and profit-sharing companies in the U.S. were begun with 
these institutions in place, and hence the presence of these plans may be endogenously determined, leading to possible sources of estimation bias. Endogeneity is a concern at the employee level as well for coops, although not for ESOPs. In ESOP companies, typically all (non-union) employees are covered by the plan. However, it is up to workers in cooperative firms whether they wish to become members, which typically involves an investment in one form or another. Clearly, workers are more apt to make this investment when it appears that there will be a positive return, and this has obvious implications for obtaining unbiased estimates of the participation effect when participation is measured by the ratio of members to the total number of workers in the firm.

Secondly, life-cycle effects are of special concern in those participative firms wherein employees participate in ownership. Miyazaki (1984), Ben-Ner (1984) and others have discussed this issue, and Estrin and Jones (1987) have been able to econometrically detect life-cycle effects for cooperatives in certain industries in France. The issue is of particular importance in the U.S., where many ESOP companies have become participative as a result of the failure of a previously existing conventional firm, and subsequently abandoned employee ownership when the firm was restored to profitability. Controlling for conditions which affect the adoption of participative agreements is necessary to obtain unbiased cconometric cstimates of the productivity effects of these arrangements.

Thirdly, most of the studies of the performance effects of employee ownership in the U.S. have adopted profitability as the performance variable. A number of interesting results have been reported [see Conte and Tannenbaum (1978 and Tannenbaum, Cook and Lohmann (1984)]; however, there are numerous problems with profit as a measure of the impact of participation. The principal problem is that increased profit performance can come about from factors other than increases in efficiency. Especially in the U.S., reorganization as an employee-owned company can have substantial tax consequences. ${ }^{2}$ Moreover, even apart from tax effects, changes in organizational structure are typically accompanied by higher levels of required debt service and requirements to repurchase the stock of retiring employees, which serves as a further drain on liquidity. The effects of these and other features of employee stock ownership plans on the statement of accounting profit are not straightforward, yet they diminish the usefulness of either before-tax or after-tax net income as an indicator of efficiency in the firm's operations. As a result, we concentrate on the underlying production function relationships to assess the impact of the various forms of participation on performance. Our strategy is to specify a flexible production function, capture as best as

\footnotetext{
${ }^{2}$ See, for example, Lowenstein (1985) for an analysis of the tax consequences of the Dan River employee stock ownership plan.
} 
we can the relevant participatory variables, and account (control) for the presence of the other factors mentioned earlier.

\section{Data and methodology}

Worker participation can be in the form of profit-sharing, individual or collective claims to assets of the firm, or a sharing in decision-making rights. In addition, workers can influence company policies and day-to-day operations via unionization.

Previous studies have assessed the impact of these varied organizational arrangements by comparing performance results from one group (e.g., a sample of producer cooperatives) with those from a sample of nonparticipative firms, or by comparing performance results within the group. While instructive, this approach does not allow for covariation among the participation variables, and opens up possibilities for misspecification and omitted variables bias. The importance of this issue is illustrated by our data.

Our data resulted from a broad ranging effort to sample four populations: (1) profit-sharing companies, (2) companies with employee stock ownership plans, (3) producer conperatives in the plywood industry, and (4) companies with programs for employee participation but with no employee ownership of profit-sharing. For each type of firm, we compiled extensive lists of possible contacts from authoritative sources and selected randomly from these lists. In the end, we received usable information from 40 companies. Responses from companies in group (4) were so limited that we abandoned our attempt to include representatives of this group in our sample. However, 13 firms in groups (1)-(3) proved to have participatory schemes and we are therefore able to estimate the effects of employee participation on productivity from our data. Nine of the 40 firms have a positive degree of unionization as well.

It is difficult to judge the representativeness of the firms in our sample in relation to the populations from which they were drawn. Hence, we do not attempt to excessively generalize our sample to the respective populations. However, the sample does reflect the high degree of covariation in participative arrangements mentioned above. Of the 11 non-employee-owned profitsharing companies in the sample, 4 indicated the presence of an active program of non-managerial employee involvement in decision-making. Of the 21 firms with ESOPs, 5 had some amount of direct non-managerial employee ownership, 7 had profit-sharing plans and 5 had some form of nonmanagerial employee participation in decision-making.

In each firm, we collected time series data on operations, including employment, fixed investment, electricity and fuels usage, sales, purchased materials, beginning and ending inventories, and industry (SIC) codes, as well as time series information on the value of employee share ownership, both directly and through and Employee Stock Ownership Trust, and the total 
equity value of the firm, from which we were able to construct measures of the percentage of company assets owned by non-managerial employees. We also collected non-time series data on the formal structures of nonmanagerial participation in decision-making, ownership and profit, as well as determining the extent of unionization of non-managerial employees in the firm.

From these data, we constructed three main operating variables: $Q=$ value added, $L=$ total hours worked and $F=$ value of electricity and fuels used. Since capital measures are questionable and since we were unable to construct an adequate direct measure of capital for more than a few of the firms, we follow part of the production function literature and use the variable $F$ as a proxy for capital services used.

In addition to $Q, L$ and $F$, we have constructed several organizational variables in order to assess the productivity impact of the various institutional (participatory) schemes. The variables that we use in this paper are:

ESOT = percentage of company stock owned by nonmanagerial employees indirectly through an employee stock ownership trust (ESOT),

DIRECTOWN = percentage of company stock owned by nonmanagerial employees directly,

PROFIT =a dummy variable coded 1.0 when the firm offers profit sharing to non-managerial employees and 0.0 otherwise,

PARTICIPATION = a dummy variable coded 1.0 when the firm has an employee participation plan and 0.0 otherwise,

UNION = percentage of the firm's labor force that is covered by a collective bargaining contract,

BANKRUPT = a dummy variable coded 1.0 if the reason for starting employee ownership was the bankruptcy of the firm and 0.0 otherwise,

PARTWAGES = a dummy variable coded 1.0 if the workers have the right to participate in decisions over wages and 0.0 otherwise,

PART PROD =a dummy variable coded 1.0 if the workers have participation in decisions over production and 0.0 otherwise,

NO OWNED = a dummy variable coded 1.0 if the firm has no nonmanagerial employee ownership and 0.0 otherwise,

TIME $=\mathrm{a}$ time trend.

All of these variables are available in at least 2 consecutive years for all but 4 of the sampled firms, and for as many as 8 consecutive years for 14 firms. The means, standard deviations and minimum and maximum values of the variables used in the analysis are presented in table 1. 
Table 1

Summary statistics of the main variables used in the analysis.

\begin{tabular}{lclll}
\hline & Mean & $\begin{array}{l}\text { Standard } \\
\text { deviation }\end{array}$ & $\begin{array}{l}\text { Minimum } \\
\text { value }\end{array}$ & $\begin{array}{l}\text { Maximum } \\
\text { value }\end{array}$ \\
\hline PROFIT & 0.58 & 0.49 & 0 & 1 \\
PARTICIPATION & 0.34 & 0.48 & 0 & 1 \\
PART WAGES & 0.14 & 0.35 & 0 & 1 \\
PART PROD & 0.03 & 0.18 & 0 & 1 \\
NOOWN & 0.42 & 0.49 & 0 & 1 \\
DIRECT OWN & 0.16 & 0.35 & 0 & 1 \\
ESOT & 0.12 & 0.25 & 0 & 1 \\
UNION & 0.15 & 0.31 & 0 & 1 \\
BANKRUPT & 0.02 & 0.14 & 0 & 1 \\
$\ln L$ & 12.2 & 1.2 & 8.0 & 15 \\
$\ln F$ & 11.8 & 1.6 & 6.9 & 16 \\
\hline
\end{tabular}

The strategy that we have adopted to estimate the productivity effects of the various schemes is to fit an augmented production function of the form

$$
Q=f(Z, A, T I M E) g(L, F),
$$

where $g$ is the input function, $f$ is the productive efficiency (total factor productivity) function and $Z$ is a vector of the institutional variables whose effect we want to estimate: $Z=(P R O F I T, P A R T I C I P A T I O N, P A R T W A G E S$, PART PROD, NOOWN, DIRECT OWN, ESOT, UNION, BANKRUPT). To operationalize eq. (1) we have taken the $g$ function to be of the transcendental logarithmic (translog) form and we allow $f$ to enter in a disembodied way,

$$
\begin{aligned}
\ln Q= & \alpha_{0}+\alpha_{1} \ln L+\alpha_{2} \ln F+\alpha_{3}(\ln L)^{2}+\alpha_{4}(\ln F)^{2} \\
& +\alpha_{5}(\ln L)(\ln F)+\beta^{\prime} Z+\varepsilon .
\end{aligned}
$$

In eq. (2), $\beta^{\prime}$ is a row vector of parameters corresponding to the $Z$ vector.

In estimating eq. (2) we have used both the ordinary least squares (OLS) and the instrumental variable (IV) methods. The former method has been shown to be robust to specification error but it may suffer from inconsistency if regressors are endogenous. The IV procedure is consistent and preferable in the presence of errors in variables. However, depending on the availability of instruments, it may generate less efficient estimates.

\section{Empirical results}

An important contribution of this study is that it provides estimates of the effects of various forms of participation together with those of unionization. 
Other studies have focused exclusively on individual participation variables or on the effect of unionization. As such, they may have suffered from omitted variables bias and led to misleading conclusions. Another special aspect of our study is that we examine the effects of both general and specific forms of participation. Accordingly, we estimate eq. (2) with both the general participation variable (PARTICIPATION), which captures the effect of the existence of a participation scheme, and with variables that capture the effects of worker participation in production and/or wage determination (PART PROD and PART WAGES).

In general, our estimates are sensitive to both the regression specification and the regression methodology (OLS vs. IV). This implies that previous results in this area may have led to false conclusions with respect to the impact of the alternative forms of participation studied here. In particular, the significance of the effects of profit-sharing and employee ownership depends on the regression specification, while the significance of the general participation variable depends upon the regression methodology. We note, however, that the impact of participation in wages is independent of the regression methodology.

As the results in tables 2 and 3 indicate, profit-sharing has a positive effect, although the coefficient is statistically significant only in the specification with the general participation variable [column (1)]. Our results are hence consistent with other studies [e.g., Jones and Svejnar (1985)] which find the effects of profit-sharing to be positive. The specification which results in a significant coefficient on profit-sharing implies that profit-sharing firms with no other forms of participation are about $32 \%$ more productive than firms which do not have profit-sharing. However, our findings suggest that the significance of the profit sharing variable may depend on the extent to which the other participation variables are specified in the equation.

Our study is the first to specify the participation variable in a more detailed way and thus raises the possibility that the strong positive effect of profit-sharing found in the earlier studies and replicated here may have been due to the inability to control adequately for the effect of specific types of worker participation in decision-making. Particularly, the implication of our results is that workers' ability to influence their own incomes, which is clearly correlated with the existence of profit-sharing but which is a broader category, may have driven the profit-sharing effect achieved in previous studies. Note that under profit-sharing the extent to which workers have a say over their own incomes is rather limited. Our results suggest that in companies which have profit-sharing programs there exist other programs as well under which workers can influence their own incomes, and it is these programs which lead to productivity gains.

The effect of the presence of worker participation, as captured by the PARTICIPATION variable, is insignificant in the OLS regression, but 
Table 2

OLS estimates of a translog production function with industry fixed effects.

\begin{tabular}{lccc}
\hline & $(1)$ & $(2)$ & $(3)$ \\
\hline $\ln L$ & -1.685 & -1.582 & -1.701 \\
& $(0.672)$ & $(0.676)$ & $(0.658)$ \\
$\ln F$ & 2.342 & 2.454 & 2.508 \\
& $(0.423)$ & $(0.420)$ & $(0.414)$ \\
$(\ln L)^{2}$ & 0.221 & 0.235 & 0.244 \\
& $(0.059)$ & $(0.059)$ & $(0.058)$ \\
$(\ln F)^{2}$ & 0.043 & 0.053 & 0.055 \\
& $(0.038)$ & $(0.042)$ & $(0.042)$ \\
$(\ln L)(\ln$ F) & 0.261 & 0.294 & 0.302 \\
& $(0.086)$ & $(0.091)$ & $(0.090)$ \\
PROFIT & 0.247 & 0.194 & 0.175 \\
& $(0.104)$ & $(0.113)$ & $(0.110)$ \\
PARTICIPATION & 0.399 & - & - \\
& $(3.303)$ & & \\
PART W AGES & - & 0.820 & 0.724 \\
& & $(0.224)$ & $(0.189)$ \\
PART PROD & - & -0.397 & - \\
& & $(0.502)$ & \\
NOOWN & -0.104 & -0.233 & -0.239 \\
& $(0.110)$ & $(0.112)$ & $(0.111)$ \\
DIRECT OWN & -2.357 & -2.151 & -2.598 \\
& $(0.473)$ & $(0.759)$ & $(0.506)$ \\
ESOT & -0.450 & -0.640 & -0.786 \\
& $(0.182)$ & $(0.271)$ & $(0.198)$ \\
UNION & 0.454 & 0.226 & 0.318 \\
& $(0.200)$ & $(0.201)$ & $(0.163)$ \\
BANKRUPT & -0.290 & -0.424 & -0.228 \\
& $(0.339)$ & $(0.401)$ & $(0.315)$ \\
TIME & 0.178 & 0.187 & 0.187 \\
& $(0.022)$ & $(0.022)$ & $(0.022)$ \\
$N$ & 155 & 147 & 147 \\
$R^{2}$ & 0.93 & 0.94 & 0.94 \\
\hline
\end{tabular}

positive and significant in the IV specification. The IV regression coefficient of 0.380 on participation suggests that firms with worker participation in decision-making are approximately $46 \%$ more productive than firms without such schemes, ceteris paribus. Schemes that accord workers the right to participate in decisions over wages are found to have a strong positive effect in all specifications. In contrast, the effect of participation in production decisions is not significantly different from zero. The estimates therefore 
Table 3

IV estimates of a translog production function with industry fixed effects.

\begin{tabular}{|c|c|c|c|}
\hline & (1) & (2) & (3) \\
\hline $\ln L$ & $\begin{array}{r}-2.086 \\
(0.816)\end{array}$ & $\begin{array}{c}-1.975 \\
(0.867)\end{array}$ & $\begin{array}{c}-2.068 \\
(0.833)\end{array}$ \\
\hline $\ln F$ & $\begin{array}{c}2.823 \\
(0.504)\end{array}$ & $\begin{array}{c}3.040 \\
(0.516)\end{array}$ & $\begin{array}{c}3.074 \\
(0.507)\end{array}$ \\
\hline$(\ln L)^{2}$ & $\begin{array}{c}0.312 \\
(0.074)\end{array}$ & $\begin{array}{c}0.345 \\
(0.078)\end{array}$ & $\begin{array}{c}0.350 \\
(0.077)\end{array}$ \\
\hline$(\ln F)^{2}$ & $\begin{array}{c}0.106 \\
(0.059)\end{array}$ & $\begin{array}{c}0.130 \\
(0.073)\end{array}$ & $\begin{array}{c}0.130 \\
(0.073)\end{array}$ \\
\hline$(\ln L)(\ln F)$ & $\begin{array}{c}-0.421 \\
(0.124)\end{array}$ & $\begin{array}{c}-0.491 \\
(0.144)\end{array}$ & $\begin{array}{r}-0.493 \\
(0.144)\end{array}$ \\
\hline PROFIT & $\begin{array}{c}0.279 \\
(0.115)\end{array}$ & $\begin{array}{c}0.238 \\
(0.125)\end{array}$ & $\begin{array}{c}0.228 \\
(0.122)\end{array}$ \\
\hline PARTICIPATION & $\begin{array}{c}0.380 \\
(0.134)\end{array}$ & - & - \\
\hline PART WAGES & - & $\begin{array}{c}0.831 \\
(0.271)\end{array}$ & $\begin{array}{c}0.771 \\
(0.226)\end{array}$ \\
\hline PART PROD & - & $\begin{array}{c}-0.213 \\
(0.532)\end{array}$ & - \\
\hline NOOWN & $\begin{array}{c}-0.167 \\
(0.126)\end{array}$ & $\begin{array}{c}-0.327 \\
(0.132)\end{array}$ & $\begin{array}{c}-0.327 \\
(0.131)\end{array}$ \\
\hline DIRECT OWN & $\begin{array}{c}-2.483 \\
(0.512)\end{array}$ & $\begin{array}{c}-2.647 \\
(0.828)\end{array}$ & $\begin{array}{r}-2.870 \\
(0.610)\end{array}$ \\
\hline ESOT & $\begin{array}{c}-0.515 \\
(0.192)\end{array}$ & $\begin{array}{c}-0.809 \\
(0.283)\end{array}$ & $\begin{array}{c}-0.882 \\
(0.216)\end{array}$ \\
\hline UNION & $\begin{array}{c}0.460 \\
(0.214)\end{array}$ & $\begin{array}{c}0.315 \\
(0.213)\end{array}$ & $\begin{array}{c}0.361 \\
(0.178)\end{array}$ \\
\hline$B A N K R U P T$ & $\begin{array}{c}-0.496 \\
(0.375)\end{array}$ & $\begin{array}{c}-0.472 \\
(0.430)\end{array}$ & $\begin{array}{c}-0.371 \\
(0.345)\end{array}$ \\
\hline$T I M E$ & $\begin{array}{c}0.176 \\
(0.026)\end{array}$ & $\begin{array}{c}0.192 \\
(0.029)\end{array}$ & $\begin{array}{c}0.191 \\
(0.029)\end{array}$ \\
\hline $\begin{array}{l}N \\
R^{2}\end{array}$ & $\begin{array}{l}155 \\
0.93\end{array}$ & $\begin{array}{l}147 \\
0.94\end{array}$ & $\begin{array}{l}147 \\
0.94\end{array}$ \\
\hline
\end{tabular}

suggest that participation is likely to have a positive overall effect, but that this effect is especially strong in those situations where workers have some control over wage determination. Moreover, allowing workers to participate in production decisions does not seem to generate productivity gains. However, the latter result may reflect the low incidence of this type of participation in our sample. (The mean of PART PROD in the sample is 0.03.) 
The sensitivity of the estimated impact of the general participation variable to the regression methodology is an important aspect of our findings. Most previous studies have found that participation in decision-making does positively influence productivity. However, several of these studies have found the impact to be insignificant. On the basis of our results, it appears that the latter findings might reflect the conditions leading to the adoption of participative management programs in the samples which lead to those results. For example, it is not unusual for firms which have experienced difficult times to adopt a more participative decision-making structure. Our results suggest that these prior conditions may have been insufficiently controlled for in estimating the effect of participative decision-making.

Our estimates relating to ownership also differ somewhat in the OLS and IV procedures. While the OLS estimates suggest that ownership has a negative effect on productivity, the IV coefficients indicate that small amounts of ownership may have a positive effect. In particular, while the coefficients on DIRECT $O W N$ and ESOT are negative and significant in all specifications, the effect of not having any employee ownership (NOOWN) is negative and significant in columns (2) and (3) of table 3. This implies that having a small amount of employee ownership affects productivity positively. However, this positive effect of having some employee ownership diminishes as the percent of non-managerial ownership increases. Our results imply that a program of non-managerial direct employee ownership at the sample mean diminishes productivity by about $17 \%$, ceteris paribus, while an ESOP which holds the sample mean fraction of company stock increases productivity by about $9 \%$.

A factor which may affect our estimate of the impact of direct ownership is that the firms in our sample with large amounts of direct ownership are concentrated in a single industry (plywood and veneer production). It may be that the negative coefficient on direct ownership reflects characteristics of that industry in the years for which we have data rather than the influence of direct ownership, per se. We intend to explore this possibility in future work.

Additionally, in connection with the above result for firms with direct employee ownership, it is important to note that most companies with large amounts of direct employee ownership also have programs for employee participation in decision-making. Hence, our results allow for the possibility that firms which have substantial direct share ownership and which simultaneously place emphasis on employee decision-making rights (worker cooperatives, for example) may be more productive than firms which have neither direct employee ownership nor employee participation in decisionmaking.

The estimated effect of unionization is positive but the significance of the estimates varies with the specification of the participation effect. The effect is significant when participation is measured as the presence of any scheme 
[column (1)] or as the presence of a scheme that allows worker participation in wage decisions. However, it becomes insignificant when participation is measured as control over both wage and production decisions. Our results indicate that the presence of various participatory schemes needs to be taken into account when evaluating the effects of unionization. Moreover, since the nature of union activities tends to be different in participatory than in traditional firms [see, e.g., Sockell (1983)] our results suggest that more indepth institutional research on the role of unions in different types of firms is needed.

\section{Concluding observations}

Our empirical findings contribute to the growing litcraturc on the effects of employee participation schemes and trade unionism on productive efficiency. Our main findings suggest that firms that offer workers participation in management tend to be more productive ones, ceteris paribus. When controlling for endogeneity of regressors, the impact of employee ownership depends on the amount of ownership. This implies that there is an 'optimal' amount of non-managerial employee ownership (if the goal is solely technical efficiency). Also when controlling for endogeneity the presence of profitsharing does not appear to affect productivity, in contrast with previous findings. Our results support previous findings on the positive efficiency impact of unionization, but indicate that this result is sensitive to regression specification.

The positive effect of participation in management gives important support to the proponents of these schemes. This is especially so since the existing studies have found the effect to be non-negative but at times insignificant.

The dependence of our results on regression specification and regression methodology implies that omitted variables bias and endogeneity are important issues in the estimation of the impact of employee participation schemes. Our results cast doubt on the validity of some previously achieved results in this area, although we do not claim the results achieved here to be definitive. Rather, we suggest that further study be given to the impact of employee participation with emphasis on covariation in the alternative ways that employees may be included in the organizational structure of the workplace.

\section{References}

Ben-Ner, A., 1984, On the stability of the cooperative type of organization, Journal of Comparative Economics 8, 247-260.

Bonin, John P., 1984, Membership and employment in an egalitarian cooperative, Economica 51 , no. 203, 295-305.

Bradley, Keith and Alan Gelb, 1981, Motivation and control in the Mondragon experiment, British Journal of Industrial Relations 19, no. 2, 211-231.

Bradley, Keith and Alan Gelb, 1982, The replication and sustainability of the Mondragon experiment, British Journal of Industrial Relations 20, no.1, 20-33. 
Cable, J. and F. Fitzroy, 1980a, Cooperation and productivity: Some evidence from West German experience, Economic Analysis Workers' Management 14, 163-180.

Cable, J. and F. Fitzroy, 1980b, Production efficiency, incentives and employee participation: Some preliminary results for West Germany, Kyklos 33, 100-121.

Conte, Michael and Arnold S. Tannenbaum, 1978, Employee-owned companies: Is the difference measurable?, Monthly Labor Review, 23-28.

Defourney, Jacques, Saul Estrin and Derek C. Jones, 1985, The effects of workers' participation on enterprise performance, International Journal of Industrial Organization 3, no. 2, 197-217.

Estrin, Saul and Derek Jones, 1987, Are there life cycles in labor-managed firms? Evidence for France, Mimeo. (Hamilton College, Clinton, NY).

Estrin, Saul, Derek Jones and Jan Svejnar, 1987, The productivity effects of worker participation: Producer cooperatives in western economies, Journal of Comparative Economics 11, 40-61.

Freeman, Richard B. and James L. Medoff, 1984, What do unions do? (Basic Books, New York).

Gelb, Alan and Jan Svejnar, 1987, Chinese township and village enterprises in a comparative perspective, Mimeo. (World Bank, Washington, DC).

Horvat, B., 1982, The political economy of socialism (Sharpe, Armonk, NY).

Jensen, Michael C. and William H. Meckling, 1976, Theory of the firm: Managerial behavior, agency costs and the ownership structure, Journal of Financial Economics 3, 305-360.

Jensen, Michael C. and William H. Meckling, 1979, Rights and production functions: An application to labor-managed firms and codetermination, Journal of Business 52, no. 4 , 469-506.

Jones, Derek C., 1985, The economic performance of producer co-operatives within command economies: Evidence for the case of Poland, Cambridge Journal of Economics 9, 111-126.

Jones, Derek C. and Jan Svejnar, 1982, Participatory and self-managed firms (Lexington Books, Lexington, MA).

Jones, Derek C. and Jan Svejnar, 1985, Participation, profit sharing, worker ownership and efficiency in Italian producer cooperatives, Economica 52, 449-465.

Jones, Derek C., Jan Svejnar and A. Zevi, 1983, The Italian system of producer cooperatives, in: J. Blasi, ed., Producer cooperatives in fifteen countries (Northwood, London).

Lill, J. Lloyd, Jr., 1984, Cooperative ventures in the United States, Review of Social Economy 42 , no. 3, 376-387.

Lowenstein, Louis, 1985, Management buyouts, Columbia Law Review 85, 730-784.

Miyazaki, Hajime, 1984, On success and dissolution of the labor-managed firm in the capitalist cconomy, Journal of Political Economy 92, no. 5, 909-931.

Rosen, Corey and William Foote Whyte, 1985, Encouraging employee ownership: The role of government, in: Employee ownership: A legislative guide (National Center for Employee Ownership, Washington, DC) 2-28.

Sockell, Donna, 1983, Toward a theory of the union's role in an enterprise, Advances in Industrial and Labor Relations 1, 221-282.

Spinnewyn, Frans and Jan Svejnar, 1986, Optimal membership, employment and income distribution in unionized, participatory and labor-managed firms (Cornell University).

Steinherr, A. and J.F. Thisse, 1979, Is there a negatively-sloped supply curve in the labormanaged firm?, Economic Analysis and Workers' Management 13, 23-33.

Svejnar, Jan, 1978, Workers' participation in management in Czechoslovakia, Annals of Public and Cooperative Economy 49, no. 2, 177-202.

Tannenbaum, Arnold S., 1974, Hierarchy in organizations: An international comparison (JosseyBass, San Francisco, CA)

Tannenbaum, Arnold S., Harold Cook and Jack Lohmann, 1984, The relationship of employee ownership to the technological adaptiveness and performance of companies, Research report (University of Michigan, Ann Arbor, MI).

Thomas, Henk and Chris Logan, 1982, Mondragon - An economic analysis (Allen and Unwin, London).

Vanek, Jaroslav, 1970, The general theory of labor-managed market economies (Cornell University, Ithaca, NY).

U.S. General Accounting Office, 1986, Employee Stock ownership plans: Interim report on a survey and related economic trends (U.S.G.P.O., Washington, DC).

Woodworth, Warner, 1984, Cooperative movements in the U.S.A.: The third stage, Annals of Public and Cooperative Economy 56, no. 3, 239-251. 